\author{
Dr. sc. Tone Jagodic \\ Olympic Committee of Slovenia, Ljubljana \\ Dr. sc. Zlatko Mateša \\ Zagreb School of Economics and Management, Zagreb
}

\title{
THE LEGAL ASPECTS OF AMBUSH MARKETING
}

\author{
UDK: 796.078 \\ Accepted: 20. 01. 2019. \\ Original scientific paper
}

\begin{abstract}
As sponsorship is a vital tool for new sources of money for sport it is important to set certain standards which should be strictly protected. Ambush marketing represents an activity which could harm the essence of the sponsorship. It may take any number of forms but essentially, it is an attack on the exclusivity which most commercial partners of sport seek and wish, to a limited extend, obtain. Exclusivity of sponsors is the element of sponsorship which is most commonly attacked by parasitic companies. The media (especially TV) play a decisive role of public opinion regarding the connection of sponsor and sponsored subject. It is obvious that ambush marketing can only be done intentionally, not by negligence. In some cases of ambush marketing the involvement of athletes is evident. An athlete should be aware of his responsibilities, a precise examination of obligations in different sponsorship agreements with sponsors of athletes and their teams should be made to avoid "internal" ambush. One of the most important factors is to determine the relationship between the sponsors of an athlete and the sponsors of his/her (national) team. Most sports organizations (clubs, national federations, NOCs, International federations, IOC) are in the position that they can not survive without sponsorship funds. That is why it is important to work with their athletes on different levels to prevent ambush marketers to use athletes to make a lot of harm into the relationship with the official sponsors. Legal protection against ambush marketing is vital for different types of sponsorship and endorsements. Prevention and immediate response to attempts of ambush marketing is crucial as sponsors are extremely sensible and closely watch the way of athlete behavior in case of ambush marketing. Passing of special laws against ambush marketing represent very useful legal support for organizers of sports competitions. It is very important that sponsors and other rights holders have an active policy of the registration and protection of all intellectual property rights associated with a sport event.
\end{abstract}

Key words: sponsorship, exclusivity, sponsor, athlete, Olympic, intellectual property rights, agreement

\section{INTRODUCTION}

Development of top sport with all consequences of commercialization brings new dimensions regarding law protection of different parties involved. Sponsorship as an important and, for many countries, main tool for new sources of money for 
sport, sets some standards which should be strictly protected. One of the main characteristics of sponsorship is exclusivity, which makes sponsorship for sponsors so attractive. Abuse of sponsorship rights, especially exclusivity, could dangerously harm relationship between sponsor and sponsored party.

Ambush marketing is a form of marketing where a company takes advantage of the publicity provided by a major event to create awareness for its product without having to contribute or make any financial commitment to the sponsorship of the event. Ambush marketing tends to contrast with the general run of commercial conflicts in sport in that it consists of an unauthorized association by businesses using one or more elements of their business (usually their name, trade mark, or a particular product or service which they supply) with an event, team or individual. Ambush marketing operates by claiming or inferring a false relationship between a rights owner without that rights owner permission. ${ }^{1}$ In return, it gets some form of publicity and media coverage. It represents a marketing strategy in which an advertiser "ambushes" an event to compete for exposure against competing advertisers.

Ambush marketing is a marketing strategy where a company ambushes its competitor's marketing efforts to gain an upper hand in terms of exposure by stealing the spotlight from him. These activities usually capitalize on resources and efforts of other (competitor) brands. Ambush marketing occurs when an advertiser uses an event to its advantage without paying admission, the sponsorship fee. Most of the time ambush marketing is legal, profitable and very effective. Ambush marketing reduces the impact of official sponsors. The consumer, whose primary concern is not always knowing who sponsors are, is left in a confusion. Consumers are able to identify the sponsor's line of business, say a credit card company, but they will not be able to say exactly which is the sponsor of the event. ${ }^{2}$ Most ambush marketing campaigns capitalize on the prominence of a major event, and aim to create an "association" with the event without being an "official" partner or sponsor of the event. An advertiser may indirectly ambush an event by alluding to its imagery and themes without referencing any specific trademarks associated with it. ${ }^{3}$

\section{LEGAL DEFINITION OF AMBUSH MARKETING}

There are many different definitions of ambush marketing, which represents a specific violation of sponsorship rules.

Special attention deserves the ICC International Code on Sponsorship, which was issued in 2003 and follows the well-established ICC policy of promoting high standards of ethics in marketing via self-regulatory codes intended to complement

1 Verow, Lawrence, Mc Cormick; Sport business and the law, Jordans, page 278

2 Vincent Fisher, International Sponsorship, Symbiose Publishing, Montreal, 1995, str 45

3 See also: Jagodic, The position of an athlete in ambush marketing, IASL seminar, Johannesburg, November 2005, 
the existing framework of national and international law. ICC International Code on Sponsorship was first issued in 1992, as an expression of the business community's recognition of its social responsibilities in respect of marketing activities and communications. Under article 4 of the Code, no party should seek to give the impression that it is a sponsor of any event or of media coverage of an event, whether sponsored or not, if it is not in fact an official sponsor of the property or of media coverage. Sponsors and sponsored parties, as well as other parties involved in a given sponsorship, should avoid imitation of the representation of other sponsorships where such imitation might mislead or generate confusion, even if applied to non-competitive products, companies or events (article 3). ${ }^{4}$

\section{Classification of ambush marketing}

There are different classifications of examples of ambush marketing. Most of the ambush activities could be selected in one of categories below. ${ }^{5}$

- Unauthorized use of intellectual property rights

- Advertising

- Broadcast sponsorship

- Joint promotions

- Competitions and promotions

- Pourage agreement

- Corporate hospitality and ticketing

Ambush marketing techniques can be classified into direct and undirect categories. Direct forms of ambush marketing involve advertisers promoting themselves as being a part of or associated with an event, diluting the exposure of official sponsors and their respective campaigns-especially if they are the product of the non-sponsor's competitors, while indirect forms of ambush marketing use imagery relating to an event in advertising to evoke a mental connection with it, without specifically mentioning it.

When brands intentionally want to appear affiliated with an event for which it has no rights, directly attacking the rivals, it is referred to as direct ambush marketing. Under this type of marketing, we have predatory marketing, which is the direct attacking of the official sponsor in a bid to gain a market share and confuse the market in knowing who the official sponsor is. "Predatory" forms of direct ambush marketing involve fraudulent claims by a non-sponsor that pass themselves off as being an "official" sponsor, usually by making direct references to trademarks relating to an event, but without having any official authorization from the event's organizers to identify itself as an official sponsor or use its trademarks.

\footnotetext{
4 ICC International Code on Sponsorship, www.iccwbo.org,

5 Clasification folowed by Verow, Lawrence, Mc Cormick; Sport business and the law, Jordans, page 280
} 
An advertiser may attempt to perform a publicity stunt inside the venue itself to attract attention to their brand, such as having attendees wear attire that is associated with the company. An official sponsor can also be involved in direct ambush marketing if they perform more extensive promotional activities at an event than they were originally authorized, such as distributing branded merchandise when they were only granted advertising on signage-especially if these activities compete with those of another sponsor authorized to do so.

Another type is Coattail Ambush marketing, when a brand attempts to directly identify with an event through legitimate means other than becoming an official sponsor and property infringement which is an unauthorized use of a protected intellectual property. For example, a company which produces sporting equipment may advertise that they are the official supplier for a specific athlete or team. Similarly, a non-sponsor may choose to solely sponsor the event's telecast by a broadcaster, but not the event itself. The factual acknowledgment of a non-sponsor's involvement with the participants in an event by, for example, a television host or commentator, can also be considered an incidental form of coattail marketing, as it provides additional unpaid publicity to the brand.

Indirect Ambush Marketing happens when a brand associate itself with an event or a program indirectly - either through creating an allusion by using similar images, symbols, etc, or setting up a promotional presence at or near the event without making specific reference to the event, or by using certain theme as that of the concerned event, in order to gain more exposure and publicize their products with no intention of attacking or stealing spotlight from their competitors.

Most forms of indirect ambush marketing involve a non-sponsor making use of imagery, themes, and values similar to what the event and campaigns from official sponsors express, either positively or negatively, and without making specific references to the event itself or its trademarks. In essence, the advertiser markets itself using content that evokes a mental association with the event, and as a result, appeals to those who are aware of the event. Advertisers may use a well-known nickname for the event that is not a trademark, such as "the big game".

It can happen that marketers of official sponsors are associated with an event but they are not as concerned with the plans of their rivals. On the other side associative ambushes use the terminology which suggests that they are the official sponsors of an event. Typical indirect marketing is called distract ambushing for setting up of promotional adverts at the venue of the event without referring to the event. Values ambushing is the use of the central value or theme of an event to give the audience an impression of an association with the event. A non-sponsor may use "distractive" techniques to divert consumers' attention away from the actual event and its official sponsors using similarly indirect means; for example, a non-sponsor may saturate the area at or around its venue (including street vendors, billboards, and public transport) with a competing marketing presence. Such "saturation marketing" may either be indirectly related to the event, or be incidental and make no references at 
all. In some cases, a company may sponsor or create a similar "parallel property," designed to compete directly with a major property by evoking similar thematics.

\section{LEGAL PROTECTION OF AMBUSH MARKETING}

There are different ways of legal protection against ambush marketing on national and international level. From industrial property legislation, brand marks protection, restriction coming out of competitive law, indemnity protection to some other parts of legislation consisting of special laws introduced for protection against ambush marketing acts.

In response to the threats of ambush marketing and other forms of trademark infringement, organizers of major sporting events have sometimes required host countries or cities to implement special laws that, going beyond standard trademark law, provide regulations and penalties for advertisers who disseminate marketing materials that create unauthorized associations with an event by making references to specific words, concepts, and symbols. ${ }^{[8][9]}$ Organizers may also require a city to set up "clean zones" in and around venues, in which advertising and commerce is restricted to those that are authorized by the event's organizer-specifically, the event's official sponsors.

Some countries have decided to pass a special legislation. Following pressure from the organizers of the Cricket World Cup, the South African government has introduced legislation banning ambush marketing both before and during the tournament. The Merchandise Marks Amendment Act 2002 is drafted in very broad terms to cover what the South African calls both "ambush by way of intrusion" and "ambush by way of association". ${ }^{6}$ Under the new law, officially passed on 17 January 2003, the relevant government minister is empowered to designate an event as protected. Any unauthorized person who then uses their brand in relation to the event in a way which seeks to derive "special promotional benefit from the event" will be guilty of a criminal offence. ${ }^{7}$ South African law represents strong

6 New South African »Ambush Marketing« laws bite, www.marketinglaw.co.uk

7 Specifically, the Act states:

"(2) For the period during which an event is protected, no person may use a trade mark in relation to such event in a manner which is calculated to achieve publicity for that trade mark and thereby to derive special promotional benefit from the event, without the prior authority of the organiser of such event.

"(3) For the purposes of subsection (2), the use of a trade mark includes-

(a) any visual representation of the trade mark upon or in relation to goods or in relation to the rendering of services;

(b) any audible reproduction of the trade mark in relation to goods or the rendering of services;

(c) the use of the trade mark in promotional activities,

which in any way, directly or indirectly, is intended to be brought into association with or to allude to an event; ;.....

"(4) Any person who contravenes subsection (2) shall be guilty of an offence.

"(5) For the purposes of this section 'trade mark' includes a mark." 
legal support for sponsorship. It is common that organizers of the most important global sport competitions try to get similar legal protection from their governments.

The Organizing committees of Olympic Games in Sydney 2000, Beijing 2008 and London $2012^{8}$, European football championship in Portugal 2004, New Zeeland Rugby World Cup $2011^{9}$ were able to convince their governments to pass special laws regarding protection against ambush in connection with important international sports competitions.

Another effective way to protect sport organizations represents "Nairobi convention of the protection of Olympic symbols" which gives the legal protection of the Olympic rings globally. ${ }^{10}$ Similar protection of the Olympic symbols can be found in some countries, where NOC initiated protection of their symbols on their territories. These laws represent a fundamental legal grounding for protection of marketing activities which use Olympic symbols as their most important marketing tools.

As IOC is extremely concerned about ambush marketing the special provision was introduced in the Olympic Charter. Rule 40 of the Olympic Charter forbids all Olympic athletes from participating in marketing activities for companies that are not official sponsors of the Olympics, even if they have official relationships with the advertiser, during a timeframe that begins 9 days before the opening ceremony, and ends 3 days after the Games' conclusion. This includes advertising material containing "Olympic-related terms," including the current year, the host city's name, "Games," "Olympians," "Sponsors," "Medal," "Gold," "Silver," "Bronze," "Challenge," "Effort," "Performance," and "Victory". ${ }^{11}$

Apart from special laws regarding protection against ambush marketing there are also some other legal possibilities how to combat with ambush marketing. The most effective are legal means coming out of rules, which govern intellectual property rights.

8 The United Kingdom passed the London Olympic Games and Paralympic Games Act 2006 prior to the 2012 Summer Olympics on top of existing laws providing special protection for Olympic symbols, the act banned the use of the words "2012" and "Games" by non-sponsors, either together, or with words or concepts relating to the event, such as "Gold," "Silver," "Bronze," "Medals," "Summer," "Sponsors," or "London," to imply an association with the Games. LOCOG also announced plans to enforce these rules in the internet keyword advertising market.

9 Prior to the 2011 Rugby World Cup, New Zeeland "Major Events Management Act," which prohibits any promotional use of words, emblems, and concepts implying association with events specifically designated as "major" by the national government, without permission from the event's organizers. The law also provides the ability for clean zones to be established around event sites for the purposes of enforcing advertising rules and providing crowd control.

10 Nairoby treaty on the protection of the Olympic Symbol, adopted in Nairoby september 26, 1981, available on web site WIPO - Administrated treaties

11 Rule 40 of the Olympic Charter: "To participate in the Olympic Games, a competitor, team official or other team personnel must respect and comply with the Olympic Charter and World Anti-Doping Code, including the conditions of participation established by the IOC, as well as with the rules of the relevant IF as approved by the IOC, and the competitor, team official or other team personnel must be entered by his NOC;" available on web site www.olympic.org 
At its most blatant, ambush marketing (also known as parasitic marketing) takes the form of actionable legal wrong such as trademark infringement or passing off. There may also be trade descriptions offences which can be dealt with by Trading Standards offices and right owners acting in unison. ${ }^{12}$

\section{EXCLUSIVITY IN SPONSORSHIP CONTRACTS}

Exclusivity is common in endorsements and corporate sponsorship contracts. Ambush marketing may take any number of forms but essentially it is an attack on the exclusivity which most commercial partners of a sport seek and will to a limited extend obtain. Legal protection against ambush marketing is vitally important for the majority of modern sponsorship and endorsements.

One of the best examples of the importance of exclusivity in sponsorship is IOC marketing programme/The Olympic programme - TOP/, which proved to be one of the most successful marketing programmes in the past 20 years. TOP companies /sponsors/ receive exclusive marketing rights and opportunities within their designated product category. They may exercise these rights on a worldwide basis, and they may develop marketing programmes with the various members of the Olympic Movement - the IOC, the NOCs, and the Organizing Committees. ${ }^{13}$

The success of a sponsorship depends largely on the exclusivity granted and whether the venues in question are 'clean' venues. It is possible to grant sponsorship rights to a number of parties but usually limited to one per product/service category. The sponsor must ensure there are no existing agreements that conflict with the sponsor.

The most common target of ambush marketing is the exclusivity of the sponsor. It is important to notice that buying a sponsorship does not (and cannot) buy you the exclusive right to association with the event, but merely a right to official sponsor status plus a package of sponsorship rights. ${ }^{14}$

12 Verow, Lawrence, Mc Cormick; Sport business and the law, Jordans, page 278

13 In addition to the exclusive worldwide marketing opportunities, partners receive:

- Use of all Olympic imagery, as well as appropriate Olympic designations on products

- Hospitality opportunities at the Olympic Games

- Direct advertising and promotional opportunities, including preferential access to Olympic broadcast advertising

- On-site concessions/franchise and product sale/showcase opportunities

- Ambush marketing protection

- Acknowledgement of their support through a broad Olympic sponsorship recognition programme

14 New South African »Ambush Marketing« laws bite, www.marketinglaw.co.uk 


\section{EXAMPLES OF AMBUSH MARKETING}

The variety of different ambush activities increase, parasitic advertisers try to find new and original ways how to get advantages of the status of sponsors without paying a sponsorship fee. There is a long and distinguished history of brands, running campaigns around sporting and other events, without being official sponsors. Whether or not these activities should be seen as legitimate depends to a great extent on the nature of the activity and your own point of view. Likewise, any kind of "intrusion" ambushing which involves trespass on property or breach of ticket terms and conditions will tend to be problematic.

Certain types of "ambush by association" are clearly hard to defend. For instance, if your marketing materials suggest wrongly that you have official sponsor status, then you can expect trouble (see the successful 2002 case in Argentina against Pepsi for running ads featuring the words "Tokyo 2002" and various images and text which were said to suggest a "presumed sponsorship relationship"). And if you use registered trade marks without permission (eg FIFA WORLD CUP) then again you can expect some grief, regardless of any arguments as to whether this is the »use in a trade mark sense".

The rights holder needs to control, supervise and check a large area in order to ensure no unwelcome brands are promoted in at or around the venue (e.g. the successful ambush marketing campaign by Nike at Euro 2000 where Adidas was the official sponsor. Nike put a huge picture of Edgar Davids on the side of a building next to a venue and, as a result, viewers thought Nike was an official sponsor). There are numerous ambush attempts trying to surprise parties which have concluded official sponsorship agreements. ${ }^{15}$ During the US Open, Stella Artois placed adverts at the Long Island Rail Road station close to the Billie Jean King National Tennis Center. This made them look like the official beer partner of the game. As a matter of fact, Heineken was. For those attendees who took trains to the games, they sure would have come across at least 15 adverts that made it look like Stella Artois was sponsoring the game.

There are also many other cases of ambush marketing which happened in connection with some important international sports competitions most often with Olympic games and Football World Championships.

The official sponsor of the USA Olympic Dream team in 1992 in Barcelona was Reebok but the Rebook logo on the track suit of players was covered up with the American flag, after which, Nike held a press conference with players from

15 Cases from website www.marketinglaw.co.uk:

1. when Linford Christie wore the Puma logo on his contact lenses at the 1996 Olympics, where Reebok was an official sponsor.

2. American Express's ad campaign in the VISA-sponsored 1994 Lillehammer Winter Olympics, featuring the slogan "If you are travelling to Lillehammer, you will need a passport, but you don't need a Visa!"

3. more recently Heineken giving away branded foam megaphones/hats outside venues at Euro 2004. 
the Olympic team. In 1996, Coca Cola acquired the rights of being the official sponsor of the cricket world cup held in India. However, to tackle the same, Pepsi launched a campaign named - "Nothing official about it' and stole the limelight from Coca Cola. The instance perhaps marks the most famous example of ambush advertising in India.

In connection with the Football World Championship 2010 in South Africa national South African Airline started a campaign to give free seats to anyone named "Sepp Blatter". (Name of FIFA president). They found someone, put up an advert and ended the advert by saying, "it's official, Sepp Blatter flies with us". Before the beginning of the competitions which was sponsored by Adidas, Nike put up an interactive advert in Johannesburg at the City's Life Center, the fourth tallest building in the city. Nike was not the official sponsor, however, it won.

Prior to the 2012 Summer Olympics in London, England, bookmaker Paddy Power announced that it was the official sponsor of "the largest athletics event in London this year": an egg-and-spoon race in the French village of London, Burgundy with a $€ 100$ credit as a prize. LOCOG threatened Paddy Power over ads for the event, but backtracked after Paddy Power threatened to take the organizing committee to court. Nike released a television advert tying into the Games with a similar concept, featuring footage of athletes training in other places named "London", and the tagline "Greatness doesn't only exist in SW19. During the Olympic Games in London, many athletes wore head phones branded "Beats By Dr Dre", whether these athletes were paid to wear these head phones, that is not known, the point is that the viewers saw the product during the event.

Pepsi ambushed Coca Cola in 2014 Football World Cup. Coca Cola signed a contract and became the official marketing partner of FIFA and had a marketing, branding and activation exclusivity in the category relating to FIFA and World Cup efforts of every Football World Cup. Pepsi ambushed this marketing effort of Coca Cola by signing 19 renowned football players including Argentinean Lionel Messi and Sergio Agüero, Englishman Jack Wilshere and Brazilian David Luiz, etc. and launching its 'Live for Now' Campaign. Though not associated with the actual event, Pepsi's marketing activities made it look like it was associated with it and this affected Coca Cola.

In July 2016, the Australian Olympic Committee sued mobile provider Telstra over adverts promoting its partnership with the Seven Network to offer subscribers free premium access to its digital coverage of the 2016 Summer Olympics, as the broadcaster's "official technology partner". The ad was set to a version of Peter Allen's song "I Go to Rio"- a phrase which was also used as the tagline of the campaign. The AOC argued that the promotion was deceiving and could imply that Telstra was an official sponsor of the Australian Olympic team (Telstra was previously an official sponsor, but ended its relationship in 2015). Telstra defended the ads, stating that they were intended to promote its relationship with the official 
broadcaster, and that it would amend the ads to disclaim that the company is not an official sponsor of the AOC or any related entities. ${ }^{16}$

\section{POSITION OF THE ATHLETES}

There are some questions regarding role of athletes in ambush activities. In principle, athletes can be (mis) used as a tool of ambush advertisers to achieve some goals connected with the attack on exclusivity of official sponsors. Is the athlete in such a case a victim of an ambush company; is he (she) responsible along with the company; which degree of knowledge about ambush marketing could be expected from an individual athlete?

The image of athletes could also be the harmed by ambush marketing, either alone or together with their sports organizations. Unauthorized use of intellectual property rights regarding the image of famous athlete is the classic case of such an abuse.

One of the most important factors is to determine the relationship between the sponsors of an athlete and sponsors of his/her (national) team. Athletes are involved in many different sports competitions with different rules regarding the rights of individual commercial promotion. It is vital to know who owns the rights of each competition and which rules should be followed. It is well known that the Olympic Charter proposes limited possibilities for commercial promotion. All athletes who wish to get accreditation for the Olympics have to sign a special Olympic declaration in which they agree to respect the rules of the Olympic Charter. Beside that NOC-s are also responsible for the behavior of their athletes and could be sanctioned for the infringements of their athletes.

Most developed NOCs prepare and sign contract prior to the Olympic Games with Athletes, Officials and National Federations. The aim of the contracts is to clarify rights and obligations of parties taking part at Olympic Games. His includes common rules coming out of the Olympic Charter including clothing rules, accreditation, way of behavior, anti-doping regulations and also provisions regarding commercial engagements of athletes, National Federations (NF) and NOCs. As the exclusivity of NOCs partners is primarily reserved for the period of Olympic Games in is wise to specify the time period when sponsors of athletes and NF should not be active and respect the rights of sponsors of NOCs. It is important to sign this contract in the period of preparation for the Olympic Games as athletes, their agents and sponsors can prepare for communication and promotion in the period before and after Olympic Games. Sometimes it is wise to include sponsors of athletes to join

16 On 29 July 2016, a federal court ruled in favour of Telstra, stating that there was "no doubt" the campaign was relating to the Games without using its trademarks, but that it was "not enough for the AOC to prove that the advertisements were Olympic-themed." 
Dr. sc. Tone Jagodic i dr. sc. Zlatko Mateša: The legal aspects of ambush marketing Zbornik radova Pravnog fakulteta u Splitu, god. 56, 2/2019, str. 271.- 284.

NOCs sponsors for the year of Olympic Games but in this case the agreement should be reached between sponsor of the athlete and NOCs. ${ }^{17}$

There were some other cases where sponsors of individual athletes made ambush marketing towards the sponsors of the national (Olympic) team ${ }^{18}$ or the organizers of Olympic Games ${ }^{19}$ Some cases are well known in connection with football stars. ${ }^{20}$ It is evident that sponsors behind athletes who they support are trying to use their image to penetrate into the area of the competition where they are not official sponsors. ${ }^{21}$

In the commercial world of sport, athletes are supposed to follow main principles of sponsorship. Participation in advertising campaigns with the aim to make harm to official sponsors is not the behavior, expected from professional athletes. Therefore, I see no reason why an athlete would not be responsible for wrongdoing together with "ambush company", if all the elements of ambush marketing are proved. Many professional athletes have their own legal advisers who should be able to distinguish prohibited campaigns from common advertising.

17 Such case was the sponsor of Slovenian athlete Tina Maze sponsor Tekanne which joined sponsors of NOC of Slovenia in the period of Olympic year 2010. The sponsor found out that is better to make an agreement with NOC and be active also during and after Olympic Games in Vancouver than to risk to have a conflict with NOC and its sponsors.

18 Such a case was the behavior of another Slovenian athlete Primož Kozmus who won the gold medal at Peking 2008 Olympics and who did not care about the restrictions for one of his sponsors and advertised it during the period closely followed after the conclusion of the games originally reserved for NOCs sponsors. NOC of Slovenia was in the position to sue the athlete but finally did not decide to put him before the court although from the legal point it was clear that the violation of the contract was evident.

19 At the 2008 Summer Olympics in Beijing, the IOC worked with the local organizing committee to develop a "robust brand-protection program"; logos of non-sponsors were covered with tape on equipment at Games facilities - a restriction that applied even to appliances, bathroom fixtures, elevators, and fire extinguishers. However, there was a high-profile ambush during the opening ceremony; former Olympic gymnast Li Ning, who founded a Chinese shoe company, lit the Olympic cauldron. The Li-Ning company was not an official sponsor of the Games (but did act as an equipment supplier for some of China's teams), and $\mathrm{Li}$ wore Adidas appeal for the sequence per its official sponsorship. On the first trading day following the ceremony, Li-Ning's share price increased by $3.52 \%$

20 PepsiCo has endorsement contracts with a number of top football players participating in the Japan/Korea FIFA World Cup 2002. These include David Beckham, Juan Sebastian Veron, Emmanuel Petit, Rivaldo and Rui Costa. However, unlike Coca-Cola which has been an official sponsor of the FIFA World Cup for 24 years, PepsiCo is not an official sponsor of the tournament. During the tournament, Pepsi ran a number of advertisements in various countries featuring the footballers on its endorsement roster in conjunction with the phrase "Tokyo 2002" and the Pepsi logo. FIFA were able to obtain a court injunction in Argentina restraining PepsiCo from using one such advertisement, on the basis that it suggested a "presumed sponsorship relationship" and could therefore cause confusion among consumers. FIFA is apparently taking proceedings in Ecuador in relation to similar commercials and has also locked horns with PepsiCo in Mexico; "Fourth referee for FIFA 'ambush marketing' claims against Pepsi?", www.marketinglaw.co.uk

21 Coca Cola signed a contract and became the official marketing partner of FIFA and had a marketing, branding and activation exclusivity in the category relating to FIFA and World Cup efforts of every Football World Cup. Pepsi ambushed this marketing effort of Coca Cola by signing 19 renowned football players including Argentinean Lionel Messi and Sergio Agüero, Englishman Jack Wilshere and Brazilian David Luiz, etc. and launching its 'Live for Now' Campaign. Though not associated with the actual event, Pepsi's marketing activities made it look like it was associated with it and this affected Coca Cola. 


\section{CONCLUSION}

Ambush marketing represents an activity which could harm the essence of the sponsorship. It may take any number of forms but essentially, it is an attack on the exclusivity which most commercial partners of sport seek and wish, to a limited extend, obtain. Exclusivity of sponsors is the element of sponsorship which is most commonly attacked by parasitic companies. The media (especially TV) play a decisive role of public opinion regarding the connection of sponsor and sponsored subject.

It is obvious that ambush marketing can only be done intentionally, not by negligence. In some cases of ambush marketing the involvement of athletes is evident. An athlete should be aware of his responsibilities, a precise examination of obligations in different sponsorship agreements with sponsors of athletes and their teams should be made to avoid "internal" ambush.

The image of athletes could also be harmed by ambush marketing activities, either alone or together with their sports organizations. One of the most important factors is to determine the relationship between the sponsors of an athlete and the sponsors of his/her (national) team. Most sports organizations (clubs, national federations, NOCs, International federations, IOC) are in the position that they can not survive without sponsorship funds. That is why it is important to work with their athletes on different levels to prevent ambush marketers to use athletes to make a lot of harm into the relationship with the official sponsors. It is not enough to organize training process with the best coaches and scientific support, but it is of the crucial essence to engage managers with business backing and sponsorship experience to work with athletes and their trainers to prevent activities which could make a lot of harm in the sport environment, where they work.

Legal protection against ambush marketing is vital for different types of sponsorship and endorsements. Prevention and immediate response to attempts of ambush marketing is crucial as sponsors are extremely sensible and closely watch the way of athlete behavior in case of ambush marketing. Passing of special laws against ambush marketing represent very useful legal support for organizers of sports competitions. It is very important that sponsors and other rights holders have an active policy of the registration and protection of all intellectual property rights associated with a sport event. 


\section{List of references}

- Bergant Rakočevič, Pravno varstvo olimpijskih simbolov, Ljubljana, Šport review, Ljubljana, 2004,

- Bergant Rakočevič, Marketing iz zasede, Pravna praksa, Ljubljana, 2003,

- Fischer, International Sponsorship, Symbiose Publishing, Montreal, 1995,

- Gaille Brandon, 12 Awesome Ambush Marketing Examples, more on https:// brandongaille.com,

- Jagodic, The position of an athlete in ambush marketing, IASL seminar, Johannesburg, November 2005,

- Jagodic, Značilnosti in posebnosti sponzorske pogodbe, Pravna praksa, Ljubljana, 2003 ,

- Jagodic, "Legal characteristics of sponsorship contracts in Olympic movement" doctoral dissertation, Faculty of Law, Ljubljana, 2007

- Jagodic: Ekskluzivnost sponzorja kot element sponzorske pogodbe, Olympic Committee of Slovenia law seminar, Ljubljana 1996

- Johnson, Examining the latest strategies to protect the exclusivity of sponsors, 2nd Annual Sports Sponsorship Contracts 2007, The Lawyer conferences, januar 2007

- Levovnik, Sponzorska pogodba, Faculty of Law, Ljubljana 2001

- Lewis; The Right of Publicity, Hendricks\& Lewis, 2004, www.hllaw.com

- Nairoby treaty on the protection of the Olympic Symbol, adopted in Nairoby september 26, 1981, available on web site WIPO - Administrated treaties

- Pahwa Aashish, What is Ambush Marketing, https://www.feedough.com/ambushmarketing,

- Thiele, Sponsoring im Osterreichischen Recht, www.eurolawyer.at/pdf/sponsoring. pdf

- Verow, Lawrence, McCormick, Sport, business and the law, Jordans, 1999

- Vincent, Fisher, International Sponsorship, Symbiose Publishing, Montreal, 1995,

\section{Web pages}

- http://www.olympic.org/

- www.iccwbo.org.

- www.marketiglaw.co.uk.

- http://www.iasl.org/ 


\begin{abstract}
SAŽETAK
Kako je sponzorstvo vitalni alat za nove izvore novca za sport, važno je postaviti određene standarde koji bi trebali biti strogo zaštićeni. Pojava ambush marketinga predstavlja aktivnost koja može naškoditi suštini sponzorstva. Može imati brojne oblike, ali u biti, to je napad na ekskluzivitet koji većina komercijalnih partnera sporta traži i želi, u ograničenoj mjeri, dobiti. Ekskluzivnost sponzora je element sponzorstva koji najčešće napadaju parazitske tvrtke. Mediji (posebno TV) igraju odlučujuću ulogu javnog mnijenja u vezi s povezivanjem sponzora i sponzoriranog subjekta. Očito je da se ovaj oblik prikrivenog marketinga (ili marketinga iz zasjede) može obaviti samo namjerno, a ne nemarno. U nekim njegovim slučajevima vidljivo je sudjelovanje sportaša. Sportaš bi trebao biti svjestan svojih odgovornosti: treba postojati precizan pregled obveza u raznim sponzorskim ugovorima sa sponzorima sportaša i njihovim timovima kako bi se izbjegla "unutarnja" zasjeda. Jedan od najvažnijih čimbenika je utvrđivanje odnosa između sponzora sportaša i sponzora njegovog (nacionalnog) tima. Većina sportskih organizacija (klubovi, nacionalni savezi, NOK-ovi, međunarodne federacije, MOO) su u poziciji da ne mogu preživjeti bez sponzorskih sredstava. Zbog toga je važno raditi sa svojim sportašima na različitim razinama kako bi se spriječili trgovci iz zasjede da koriste sportaše kako bi mnogo naštetili u odnosu s službenim sponzorima. Pravna zaštita od marketinga u zasedi od vitalne je važnosti za različite vrste sponzorstava i potpora. Prevencija i neposredan odgovor na pokušaje ambush marketinga ključni su jer su sponzori izuzetno osjetljivi i pažljivo prate način ponašanja sportaša u ovim slučajevima.Donošenje posebnih zakona protiv ambush marketinga predstavlja vrlo korisnu pravnu podršku organizatorima sportskih natjecanja. Vrlo je važno da sponzori i drugi nositelji prava imaju aktivnu politiku registracije i zaštite svih prava intelektualnog vlasništva vezanih uz sportski događaj.
\end{abstract}

Ključne riječi: sponzorstvo, ekskluzivnost, sponzor, sportaš, olimpijski, prava intelektualnog vlasništva, sporazum 